\title{
Development and Quality Analysis of Instant Soup Mix from Moringa oleifera Pod Powder
}

Faruk Ansari* Alpana Singh and Sanjay Patidar

JNKVV, Jabalpur, MP, India

*farukansarik0786@gmail.com

\section{ABSTRACT}

Traditionally Moringa is known as mystical miracle tree or the tree of life. Soup can be classified as an appetizer, warm food during cold and sick. Moringa oleifera pods have been procured from College of Agriculture, JNKVV, Jabalpur. The present investigation is planned with objectives to standardize best combination of for the development of instant soup mix, to evaluate various quality parameters, to evaluate the storage stability and cost estimation of product. Protein in instant soup is ranged from 9.76 to 11.89 percent in different formulations of instant soup mix. Formulation MPP4 (11.89) had significantly maximum protein content followed by MPP3, MPP2, MPP1 and Control with the minimum protein content. The original instant soup mix (control) exhibited highest carbohydrate content $(61.52 \%)$ followed by MPP1, MPP3, MPP4, and MPP2 with lowest content. The evaluated scores of control for colour and appearance, taste, flavour, consistency, after taste and overall acceptability are 8.36, 8.50, 8.60, $8.90,8.76$ and 8.63 respectively.

Keywords: - Moringa, pods, instant soup mixes, proximate, sensory and storage study.

\section{INTRODUCTION}

Moringa oleifera Lam. (Moringaceae) is traditionally known as mystical miracle tree or the tree of life. Moringa can withstand both severe drought and mild frost conditions and hence widely cultivated across the world. In India, Thailand and the Philippines, Moringa tree is commonly grown in home gardens and the leaves and immature pods are sold in the local markets as soup ingredient (Foidl et al. 2001).

Various parts Moringa oleifera plant such as the leaves, roots, seed, bark, fruit, flowers and immature pods used since ancient times. It used as extremely rich in vital nutrients and medicinal value, known to heal and ease many diseases: from various inflammations to parasitic diseases, diabetes, cardiac, circulatory stimulants, antipyretic, antitumor, anti-inflammatory, antiepileptic, diuretic, antiulcer, antispasmodic antihypertensive, cholesterol lowering, antidiabetic, antioxidant, antibacterial, hepatoprotective, antifertility, antifungal activities and cancer else (Shah et al. 2016).

Soup is one of the traditional foods which can be classified as an appetizer, warm food during cold and sick. In the modern world commercially prepared instant soup has replaced homemade soup as preparing a soup is a time consuming process (Niththiya et al. 2014). Soup is generally made by combining ingredients such as vegetables green leaves with juice, water, or other liquid. Hot soups are additionally characterized by boiling solid ingredients in liquids in a pot until the flavors are extracted, forming a broth. Ingredients commonly used to thicken soups and broths include rice, lentils, flour, and grains.

Increase in population and accumulation of industries made more people to stay alone after education for employment. Less time is available for them to prepare food. Hence most of them consume foods that requires less preparation time without considering the health benefits. 
Instant soups play an important role in balancing the nutrients required for the people to stay healthy and can become an alternative food for breakfast (Mathangi, et al. 2017).

Dried soup powders have an advantage of protection from enzymatic and oxidative spoilage and flavor stability at room temperature over long periods of time (6-12 months). In addition, they are ready for reconstitution in a short time for working families, hotels, hospitals, restaurants, and institutional use as well as to military rations. Moreover, they exert light weight for shipping and availability at all time of the year (Rekha, 2010).

\section{MATERIALS AND METHODS}

Food commodities: - Moringa oleifera pods have been procured from College of Agriculture, JNKVV, Jabalpur. Sugar, corn starch, cumin, black pepper, salt, green pea, cabbage, carrot, coriander, garlic, onion, tomato, lentil, sanwa millet, citric acid, sodium benzoate were collected from market of Jabalpur. Good quality of Moringa pods were cleaned properly by removing the insect damaged and deteriorated, stem and the good quality parts were selected for drying.

Dehydration of Moringa parts, spices and vegetables: - The cleaned pods were blanched by steam for 3 minutes. And pods dried in hot air oven at $55^{\circ} \mathrm{C}$ for 16 hours (Parvathi et al., 2015). The fresh spices and vegetables were cleaned, chopped into small pieces and dried in hot air oven at $65^{\circ} \mathrm{C}$ for 5-6 hours. Preparation of instant soup mix: - A proportion of ingredients, sample combinations, cooking and accordingly percentage of supplementation was established through sensory evaluation. Several compositions of raw materials and main ingredients were tried to arrive at the desired formulation with optimum percentage as recommended by acceptability studies. All experimental samples were prepared using the method of Amal et al., (2014) with slight modification various acceptability parameters such as consistency, colour, appearance, flavour, taste, after taste and overall acceptability were considered as deciding factors by using the method described by Amerine et al., (1965). Physical properties:-Reconstitution Index (RI) The reconstitution index of the samples was determined according to method described by Onwuka (2005). Water absorption capacity (WAC) - The gain in mass was the water absorption capacity of the soup sample. The volume difference gave the volume of water absorbed by $1 \mathrm{~g}$ of the test sample. Absorption capacity is expressed in grams of water absorbed per gram of sample (Onwuka, 2005). Bulk density (BD) determination- A graduated cylinder (10 ml) was gently filled with the flour sample. The bottom of the cylinder was then tapped gently on a laboratory bench several times. This continues until no further diminution of the test flour in the cylinder after filling to mark, was observed (Onwuka, 2005). Rehydration Ratio (RR) - Rehydration ratio was defined as the ratio of weight of rehydrated samples to the dry weight of the sample (Krokida and Marinos-Kouris, 2003). Swelling index (SI) - The method as described by Ukpabi and Ndimele (1990) was used in the determination of the swelling index. Hunter Colour Measurement- Colour measurement of different instant soup mixes was done by using a Hunter colour measuring system and expressed in terms of $\mathrm{L}^{*}, \mathrm{a}^{*}, \mathrm{~b}^{*}$, according to the CIE method (1976). Chemical properties:-All the experiments were carried out in duplicate and mean values have been reported. The instruments used were properly calibrated and standardized procedures were followed for the valid and reliable analysis. Proximate composition of instant soup mix- The nutritional evaluation of instant soup mix with respect to various constituents was carried out by the following procedures. Determination of Moisture content- The moisture content of the sample was determined by using moisture meter. Determination of Protein content- The protein content 
in sample was determined by using conventional Micro-Kjeldhal digestion and distillation procedure as given in AOAC (1992) using Pelican's Kel Plus digestion and distillation assembly. Determination of Fat content- The fat content of the sample was determined by the procedure as described in AOAC (1992) using Pelican's Socks plus automatic fat analysis system. Determination of Ash content- The ash content present in the sample was determined according to the procedure given in AOAC (1992) using Muffle furnace. Determination of Crude fibre- The crude fibre was determined by the method as described in AOAC (1992) using automatic fibre analysis system- Fibra Plus (Make- Pelican). Determination of Total Carbohydrates- Total carbohydrate was estimated by subtracting the sum of moisture, protein, fat, ash and crude fibre from 100 (Merrill and Watt, 1973). Storage studies- All samples were drawn periodically after 0, 30, 60, 90 days and analyzed for sensory qualities, moisture, microbial count and hunter colour analysis. The total plate count was done by using the method of Aneja, (2003). Sensory analyses:-The sensory quality characteristics were evaluated by Amerine et al. (1965). Microbial evaluation: - Method adopted by Ranganna (2009). Statistical analysis- A complete randomized design was adopted for statistical analysis of data by following the procedure as described by Panse and Sukhatme (1985).

\section{RESULTS AND DISCUSSION}

Development and optimization of instant soup mix:- Development and Optimization:- A number of trials were conducted by taking varying Moringa oleifera parts sugar, corn starch ,cumin, black pepper, salt, green pea, cabbage ,carrot, coriander, garlic, onion, tomato, lentil , sanwa millet, citric acid and sodium benzoate. Accordingly soup was prepared using basic recipe for soup with 10 to $30 \%$ Moringa parts, 10 - 38\% lentil, 2 to $5 \%$ salt and sugar 7 to $10 \%$ cornstarch as depicted in table 1. Finally soup were prepared using the optimum level of ingredients arrived at desired formulations from the earlier results of acceptability studies of soup formulations.

In the preliminary sensory evaluation test different soup were prepared from different formulations and were evaluated by panelists. The score for the product with $16-22 \%$ Moringa leaf /flower, $20-26 \%$ Moringa pod powder, 24 to 25\% sanwa millet , 13-35\% lentil powder , $10-11 \%$ tomato powder were are acceptable in terms of all sensory attributes. Panelists suggested the $4 \mathrm{~g}$ of salt and sugar, $0.5 \mathrm{~g}$ black pepper, 10 to $11 \%$ tomato powder for improving the taste and colour of modified instant soup mixes. They also suggested to take $8 \mathrm{~g}$ of corn starch for instant medicinal soup mix as the soup with $10 \%$ corn starch was too thick and $7 \mathrm{~g}$ of corn starch was too thin. They also suggested increasing the cooking time of instant soup mix up to 6 minutes. The use of green pea grits was recommended in place of whole seed in the formulations. On the basis of above findings the levels of ingredients and method of preparation was finalized.

Physical attributes of instant medicinal soup mixes:- Reconstitution Index:- The observed Reconstitution Index with different combinations of instant soup in pod powder soup mix, the rehydration ratio was found to be highest in MPP4 $(17.50 \mathrm{~g} / \mathrm{ml})$ and lowest in control $(14.30 \mathrm{~g} / \mathrm{ml})$ (Table 2). Water absorption capacity:-The WAC in Moringa pod instant soup mix, ranged from 270 to $290 \mathrm{ml} / 100 \mathrm{~g}$ and the highest value of WAC was found in control $(290 \mathrm{ml} / 100 \mathrm{~g})$ followed by MPP4 (285ml/100g) and lowest in MPP1 (270ml/100g). (Table 2). Bulk Density: - The bulk density of instant mixes ranged $0.67-0.72 \mathrm{~g} / \mathrm{ml}$ in Moringa pod powder. Rehydration ratio: - The rehydration ratio of Moringa pod powder instant soup mix varied from 2.5 to 6.63 and was 
highest in MPP4 and lowest in control Table (6-8). Swelling index: - In pod powder soup mix, the swelling index was found to be highest in MPP4 (1.71) and lowest in control (1.33). Hunter colour analysis:- Instant soup mix from MPP showed highest value of lightness in control followed by MPP1 (51.70), MPP4 (51.12), and MPP3 (50.80) while the lowest value (50.44) was obtained from MPP2. The highest $\mathrm{a}^{*}$ and $\mathrm{b}^{*}$ values of soup obtained from control and lowest by MPP4 (7.23, 12.98 respectively). Significant difference was observed between the treatments. (Table 4).

Proximate Analysis: - It is clear from table (3) that protein ranged from 9.76 to 11.89 percent in different formulations of instant soup mix. Formulation MPP4 (11.89) had significantly maximum protein content followed by MPP3, MPP2, MPP1 and Control with the minimum protein content. All formulations differed significantly from each other. The range of fat content was found to be 1.40 to 2.59 percent in various instant soup mix formulations. MPP2 exhibited maximum fat content as compared with other formulations and it was statistically superior to rest. The original instant soup mix (control) exhibited highest carbohydrate content $(61.52 \%$ ) followed by MPP1, MPP3, MPP4, and MPP2 with lowest content. Control was statistically superior to other formulations. The crude fibre content of instant soup mix ranged from 4.13 to 5.62 percent in various formulations. MPP4 exhibits maximum fibre content compared to the rest; hence it is statistically superior to other formulations. The ash content in different blends of instant soup mix ranged from 8.69 to 9.95 percent. MPP4 was numerically superior to rest of the formulations.

Sensory attributes of instant soup mix during storage with Moringa pod powder: - Colour and appearance:-The score in table 5 the initial values were recorded by treatment CONT (8.36) and were gradually decreased up to 8.22 on $90^{\text {th }}$ day of storage and treatment MPP4 (8.02) was decreased upto 7.80 in PP at the end of storage. Flavour:-The data revealed that an initial value of 8.60 (CONT) which was decreased gradually up to 8.34 in PP on 90th days of storage. The modified soup mix MPP4 was decreased from 8.04 to 7.75 in PP at the end of storage. Taste:-The taste of CONT (8.50) was decreased up to 8.30 in PP on 90th day of storage and treatment MPP4 (8.01) was decreased up to 7.72 in PP at the end of storage. Consistency:- The mean value of the CONT and MPP4 was 8.90 and 8.05 respectively at initial stage and was decreased during the period of storage upto 8.70 and 7.71 respectively in PP on 90th day of storage. After taste:Decreasing trend in value of the CONT and MPP4 was 8.76 and 8.03 respectively at initial stage and was decreased during the period of storage upto 8.60 and 7.74 respectively in PP on 90th day of storage. Overall acceptability: - It is observed from the data that there was a significant difference among the all packaging materials. The scores of CONT (8.63) and MPP4 (8.06) was decreased gradually up to 8.46 and 7.70 respectively at the end of storage in PP.

Total plate counts of instant soup mixes during storage: - The results shown in table 7 of microbial analysis showed increase in total plate count during storage but it was found to be under acceptable limit. The total plate count found negligible up to 30 days of storage of instant soup mixes packed in aluminium foil and very less count was observed on 90th day of storage in all soup samples. The total plate count was too less to count in all packaging materials on 0 day of storage. The yeast and mold counts were absent during storage.

Moisture content of instant soup mixes during storage: - According to Luh and Woodroof (1975), moisture content is an important factor of microorganism's growth. Microorganisms cannot grow when moisture content is below $8 \%$. The data revealed that moisture content of instant soup mixes (control) had an initial value of 8.41 percent which was increased gradually up 
to 8.64 in PP at the end of storage and in modified instant soup mixes, it ranged from 8.77 to 8.92 in MPP4 packed in PP at the end of storage as depicted in table 6.

\section{CONCLUSION}

As a general from this study, it can said that, enriched Moringa based soup mixes prepared by drying could be adopted for the development of soup mixes and supplementing soup mix with Moringa pod as a valuable food addition to enhance nutritional and sensorial profile of the instant soup. During the 90 days storage period the instant soup mix in alluminium foil was found to be best in context of overall acceptability with the intervals of 0 days 8.06, 30 days 8.06, 60 days 8.06 and 90 days 7.94 scores respectively.

The cost of production also found in acceptable level. The developed soup mix is more convenient than traditional product and this will improve its popularity among the younger generation and is a novel one holds good branding and marketing scope.

Table 1: Different formulations of instant soup mix with Moringa pod powder

\begin{tabular}{|l|c|c|c|c|c|}
\hline Formulations & Control & MPP\% & MPP\% & MPP\% & MPP\% \\
\hline MPP & $\mathbf{0}$ & $\mathbf{2 0}$ & $\mathbf{2 2}$ & $\mathbf{2 4}$ & $\mathbf{2 6}$ \\
\hline Citric acid & 0.25 & 0.25 & 0.25 & 0.25 & 0.25 \\
\hline $\begin{array}{l}\text { Sodium } \\
\text { benzoate }\end{array}$ & 0.30 & 0.30 & 0.30 & 0.30 & 0.30 \\
\hline Sugar & 2 & 2 & 2 & 2 & 2 \\
\hline Corn starch & 8 & 8 & 8 & 8 & 8 \\
\hline Cumin & 0.3 & 0.3 & 0.3 & 0.3 & 0.3 \\
\hline Black pepper & 0.5 & 0.5 & 0.5 & 0.5 & 0.5 \\
\hline Salt & 4 & 4 & 4 & 4 & 4 \\
\hline Green pea & 4 & 4 & 4 & 4 & 4 \\
\hline Cabbage & 0.3 & 0.3 & 0.3 & 0.3 & 0.3 \\
\hline Carrot & 4 & 4 & 4 & 4 & 4 \\
\hline Coriander & 0.35 & 0.35 & 0.35 & 0.35 & 0.35 \\
\hline Garlic & 1.30 & 1.30 & 1.30 & 1.30 & 1.30 \\
\hline Onion & 2 & 2 & 2 & 2 & 2 \\
\hline Tomato & 10 & 10 & 10 & 11 & 11 \\
\hline Lentil & 35 & 15 & 13 & 11 & 09 \\
\hline Sanwa millet & 25 & 25 & 25 & 24 & 24 \\
\hline Total & $\mathbf{1 0 0}$ & $\mathbf{1 0 0}$ & $\mathbf{1 0 0}$ & $\mathbf{1 0 0}$ & $\mathbf{1 0 0}$ \\
\hline
\end{tabular}

MPP= Moringa Pod Powder

Table 2: Physical attributes of instant soup mixes

\begin{tabular}{|c|c|c|c|c|c|}
\hline $\begin{array}{l}\text { Formulatio } \\
\text { ns }\end{array}$ & $\begin{array}{c}\text { Reconstitutio } \\
\mathbf{n} \\
\operatorname{Index}(\mathrm{g} / \mathrm{ml})\end{array}$ & $\begin{array}{c}\text { Water } \\
\text { absorption } \\
\text { capacity }(\mathrm{ml} / \mathbf{1 0 0} \\
\mathrm{g})\end{array}$ & $\begin{array}{c}\text { Bulk } \\
\text { densit } \\
\mathbf{y} \\
(\mathrm{g} / \mathrm{ml})\end{array}$ & $\begin{array}{c}\text { Rehydratio } \\
\text { n ratio }\end{array}$ & $\begin{array}{c}\text { Swellin } \\
\qquad \mathrm{g} \\
\text { index }\end{array}$ \\
\hline CONT & 14.30 & 290 & 0.72 & 2.5 & 1.33 \\
\hline
\end{tabular}




\begin{tabular}{|l|c|c|c|c|c|}
\hline MPP1 & 14.46 & 270 & 0.65 & 4.5 & 1.53 \\
\hline MPP2 & 17.30 & 274 & 0.66 & 4.66 & 1.66 \\
\hline MPP3 & 17.40 & 277 & 0.67 & 5.26 & 1.69 \\
\hline MPP4 & 17.50 & 285 & 0.66 & 6.63 & 1.71 \\
\hline SEM & 0.321 & 0.856 & 0.004 & 0.214 & 0.050 \\
\hline CD at 5\% & 1.025 & 2.733 & 0.014 & 0.682 & 0.161 \\
\hline
\end{tabular}

Table 3: Proximate analysis of instant soup mixes

\begin{tabular}{|l|c|c|c|c|c|c|}
\hline Formulations & $\begin{array}{c}\text { Moisture } \\
(\boldsymbol{\%})\end{array}$ & $\begin{array}{c}\text { Protein } \\
(\boldsymbol{\%})\end{array}$ & $\begin{array}{c}\text { Fat } \\
(\boldsymbol{\%})\end{array}$ & $\begin{array}{c}\text { Crude } \\
\text { fibre } \\
(\boldsymbol{\%})\end{array}$ & $\begin{array}{c}\text { Carbohydrate } \\
(\boldsymbol{\%})\end{array}$ & $\begin{array}{c}\text { Ash } \\
(\boldsymbol{\%})\end{array}$ \\
\hline CONT & 8.41 & 09.76 & 1.40 & 4.13 & 61.52 & 8.69 \\
\hline MPP1 & 8.53 & 11.40 & 2.42 & 5.03 & 60.03 & 9.76 \\
\hline MPP2 & 8.62 & 11.56 & 2.49 & 5.11 & 59.04 & 9.83 \\
\hline MPP3 & 8.73 & 11.81 & 1.52 & 5.49 & 60.84 & 9.91 \\
\hline MPP4 & 8.77 & 11.89 & 1.59 & 5.62 & 59.93 & 9.95 \\
\hline SEM & 0.010 & 0.359 & 0.168 & 0.173 & 0.355 & 0.050 \\
\hline CD at 5\% & 0.031 & 1.147 & 0.538 & 0.551 & 1.134 & 0.161 \\
\hline
\end{tabular}

Table 4: Hunter colour analysis of instant soup mixes

\begin{tabular}{|l|c|c|c|}
\hline Formulations & $\mathbf{L}^{*}$ & $\mathbf{a}^{*}$ & $\mathbf{b}^{*}$ \\
\hline CONT & 75.12 & 9.42 & 15.69 \\
\hline MPP1 & 51.70 & 8.19 & 13.06 \\
\hline MPP2 & 50.44 & 8 & 13.19 \\
\hline MPP3 & 50.80 & 7.98 & 13.05 \\
\hline MPP4 & 51.12 & 7.23 & 12.98 \\
\hline SEM & 0.900 & 0.331 & 0.381 \\
\hline C.D. at 5\% & 2.873 & 1.058 & 1.216 \\
\hline
\end{tabular}

Table 5: Sensory attributes of instant soup mix during storage

\begin{tabular}{|c|c|c|c|c|c|c|c|c|}
\hline \multirow[t]{2}{*}{ Attributes } & \multicolumn{2}{|c|}{0 days } & \multicolumn{2}{|c|}{30 days } & \multicolumn{2}{|c|}{60 days } & \multicolumn{2}{|c|}{90 days } \\
\hline & CONT & MPP4 & CONT & MPP4 & CONT & MPP4 & CONT & MPP4 \\
\hline \multicolumn{9}{|c|}{ Aluminium foil } \\
\hline $\begin{array}{l}\text { Colour } \\
\& \\
\text { appearance }\end{array}$ & 8.36 & 8.02 & 8.36 & 8.02 & 8.36 & 8.02 & 8.30 & 7.98 \\
\hline Flavour & 8.60 & 8.04 & 8.60 & 8.04 & 8.60 & 8.04 & 8.42 & 7.88 \\
\hline Taste & 8.50 & 8.01 & 8.50 & 8.01 & 8.50 & 8.01 & 8.44 & 7.96 \\
\hline Consistency & 8.90 & 8.05 & 8.90 & 8.05 & 8.90 & 8.05 & 8.82 & 7.88 \\
\hline After taste & 8.76 & 8.03 & 8.76 & 8.03 & 8.76 & 8.03 & 8.66 & 7.94 \\
\hline $\begin{array}{l}\text { Over all } \\
\text { acceptability }\end{array}$ & 8.63 & 8.06 & 8.63 & 8.06 & 8.63 & 8.06 & 8.58 & 7.94 \\
\hline \multicolumn{9}{|c|}{ LDPE } \\
\hline $\begin{array}{l}\text { Colour } \\
\& \\
\text { appearance }\end{array}$ & 8.36 & 8.02 & 8.30 & 7.96 & 8.28 & 7.88 & 8.26 & 7.84 \\
\hline
\end{tabular}




\begin{tabular}{|l|c|c|c|c|c|c|c|c|}
\hline Flavour & 8.60 & 8.04 & 8.52 & 7.92 & 8.48 & 7.87 & 8.40 & 7.80 \\
\hline Taste & 8.50 & 8.01 & 8.44 & 7.89 & 8.40 & 7.84 & 8.35 & 7.78 \\
\hline Consistency & 8.90 & 8.05 & 8.82 & 7.92 & 8.78 & 7.82 & 8.74 & 7.76 \\
\hline After taste & 8.76 & 8.03 & 8.70 & 7.94 & 8.66 & 7.83 & 8.61 & 7.80 \\
\hline $\begin{array}{l}\text { Over all } \\
\text { acceptability }\end{array}$ & 8.63 & 8.06 & 8.60 & 7.98 & 8.58 & 7.82 & 8.52 & 7.75 \\
\hline \multicolumn{7}{|l|}{ PP } \\
$\begin{array}{l}\text { Colour } \\
\begin{array}{l}\text { \& } \\
\text { appearance }\end{array}\end{array}$ & 8.36 & 8.02 & 8.28 & 7.92 & 8.25 & 7.83 & 8.22 & 7.80 \\
\hline Flavour & 8.60 & 8.04 & 8.50 & 7.86 & 8.41 & 7.82 & 8.34 & 7.75 \\
\hline Taste & 8.50 & 8.01 & 8.40 & 7.82 & 8.34 & 7.80 & 8.30 & 7.72 \\
\hline Consistency & 8.90 & 8.05 & 8.78 & 7.86 & 8.73 & 7.77 & 8.70 & 7.71 \\
\hline After taste & 8.76 & 8.03 & 8.66 & 7.90 & 8.60 & 7.78 & 8.60 & 7.74 \\
\hline $\begin{array}{l}\text { Over all } \\
\text { acceptability }\end{array}$ & 8.63 & 8.06 & 8.56 & 7.95 & 8.53 & 7.76 & 8.46 & 7.70 \\
\hline
\end{tabular}

Table 6: Moisture content of instant soup mixes during storage

\begin{tabular}{|l|c|c|c|c|}
\hline \multirow{2}{*}{ Treatments } & \multicolumn{4}{l|}{ Moisture } \\
\cline { 2 - 5 } & 0 days & 30 days & 60 days & 90 days \\
\hline AL CONT & 8.41 & 8.44 & 8.47 & 8.50 \\
\hline ALMPP4 & 8.77 & 8.79 & 8.80 & 8.82 \\
\hline LD CONT & 8.41 & 8.47 & 8.52 & 8.58 \\
\hline LDMPP4 & 8.77 & 8.81 & 8.87 & 8.91 \\
\hline PPCONT & 8.41 & 8.49 & 8.55 & 8.64 \\
\hline PPMPP4 & 8.77 & 8.80 & 8.86 & 8.92 \\
\hline
\end{tabular}

Table 7: Total plate counts of instant soup mixes during storage

\begin{tabular}{|l|c|c|c|c|}
\hline \multirow{2}{*}{ Treatment } & \multicolumn{4}{|c|}{ Mesophilic count } \\
\cline { 2 - 5 } & 0 days & 30 days & 60 days & 90 days \\
\hline PPCON & TFTC & $1.3 \times 10^{2}$ & $2.2 \times 10^{3}$ & $3.2 \times 10^{3}$ \\
\hline PPMPP & TFTC & $1.3 \times 10^{2}$ & $2.2 \times 10^{3}$ & $3.3 \times 10^{3}$ \\
\hline LDCON & TFTC & $1.3 \times 10^{2}$ & $2.2 \times 10^{3}$ & $3.8 \times 10^{3}$ \\
\hline LDMPP & TFTC & $1.3 \times 10^{2}$ & $2.2 \times 10^{3}$ & $4.0 \times 10^{3}$ \\
\hline ALCON & TFTC & $1.3 \times 10^{2}$ & $2.2 \times 10^{3}$ & $2.1 \times 10^{3}$ \\
\hline ALMFP & TFTC & TFTC & $1.3 \times 10^{3}$ & $2.2 \times 10^{3}$ \\
\hline
\end{tabular}

TFTC $=$ Too few to count 


\section{References}

Amal M H, Abdel-Haleem, Azza A and Omran. 2014. Preparation of Dried Vegetarian Soup Supplemented with Some Legumes .Food and Nutrition Sciences 5, 2274-2285.

Amerine M A, Pangborn R M and Roessler E B. 1965. Principles of sensory evaluation of food. In: Food Science and Technology Monographs. pp.338-339. Academic Press, New York.

Aneja K R.2003 Experiments in microbiology, Plant Pathology and Biotechnology IV edition. Newage international ltd. publication.

AOAC. 1992. Official methods of analysis 16th edition. Association of official Analytical Chemists Inc., Arlington VA.

CIE .1976. Publication No. 15, Colorimetry.

Foidl N, Makkar HPS and Becker K. 2001. The potential of Moringa oleifera for agricultural and industrial uses. In: The Miracle Tree/The Multiple Attributes of Moringa (Ed. Lowell J Fuglie ) CTA. USA.

Krokida M K and Kouris D M. 2003. Rehydration kinetics of dehydrated products. Journal of food engineering, 57, 1-7.

Luh B S and Woodroof J G. 1975. Commercial vegetable processing. Westport the Avi publishing company Inc.

Mathangi S S, Geethanjali S S, Visalachi V. 2017. Development and formulation of instant soup mix from sprouted horse gram and radish leaves, International Journal of Home Science 2017; 3(1):346-349.

Merrill, A L. and Watt, B K. 1973. Energy Value of Foods: Basis and Derivation. Agriculture Handbook No. 74, ARS United States Department of Agriculture, Washington DC.

Niththiya, Vasantharuba, Subajini M B and Srivijeindran. 2014. Formulation of Instant Soup Mix Powder Using Uncooked Palmyrah (Borassus flabellifer) Tuber Flour and Locally Available Vegetables. Proceedings of Jaffna University International Research Conference.

Onwuka G I. 2005. Food Analysis and Instrumentation. Theory and Practice. Naphtali Prints. Surulere Lagos Nigeria. 133 - 137.

Panse V G and Sukhatme P V. 1985. Statistical Methods for Agrilculture, Wo., 4th ed., ICAR, New Delhi, 347 p.

Parvathi S M, Nithya J, Devi P and Yogeshwari R. 2015. Effects of different drying methods and value addition of versatile food mix with Moringa dry leaves. International Journal of Home Science Extension and Communication Management. 2(1), 8-12.

Rekha M N A, Yadav R, Dharmesh S, Chauhan A S and Ramteke R S. 2010. Evaluation of Antioxidant Properties of Dry Soup Mix Extracts Containing Dill (Anethum sowa L.) Leaf. Food and Bioprocess Technology, 3, 441-449.

Shah S K, Jhade D N and Chouksey R. 2016. Moringa oleifera Lam. A Study of Ethnobotany, Nutrients and Pharmacological Profile. Research Journal of Pharmaceutical, Biological and Chemical Sciences 7(5): 2158-2162. 
Ukpabi U J and Ndimele C. 1990. Evaluation of Gari Production in Imo State Nigeria. Nigeria Food Journal, 8, 105-110. 